\title{
Crisis Management for Public Sector during the European Financial Crisis: Lessons of Estonia in 2008-2011
}

\author{
Raul Markus $^{1}$ and Viljar Veebel ${ }^{2}$ \\ ${ }^{1}$ Tallinn University of Technology, Tallinn, Estonia \\ ${ }^{2}$ Tartu University, Tartu, Estonia
}

Correspondence should be addressed to: Viljar Veebel; Viljar.Veebel@ut.ee

Received date: 27 September 2017; Accepted date: 23 November 2017;

published date: 21 March 2018

Academic Editor: Boris I. Sokolov

Copyright (C) 2018. Raul Markus and Viljar Veebel. Distributed under Creative Commons CC-BY 4.0

\begin{abstract}
The austerity implementation experience of the Estonian Government during the European financial crisis has high value both in practical terms when improving preparations for future crises, and as a case for academic research, especially when compared with the other Baltic States and Visegrad countries. The crisis response was even more complicated as a simultaneous goal was set to fulfil Eurozone accession criteria. When studied carefully, the Estonian experience is valuable from the wider future perspective as it offers experience and answers to whether extreme austerity is an efficient solution to counter a financial crisis, the economic and social costs it includes, the best administrative practices to be suggested when implementing austerity and some hints how to implement unpopular austerity politically.
\end{abstract}

Keywords: European Union, austerity, public sector, financial crisis

\section{Introduction}

The economic developments, financial choices, political dilemmas and final achievements of the Baltic States in the years of financial crisis (2008-2011) offer both valuable practical experience and academic inspiration for research. These countries, while following similar goals and paths between regaining independence and accession to the European Union (EU) in 2004, have chosen in many aspects different priorities after the EU accession, which led them into different economic and political situations at the beginning of global financial crisis in the year 2008.

Cite this Article as: Raul Markus and Viljar Veebel (2018)," Crisis Management for Public Sector during the European Financial Crisis: Lessons of Estonia in 2008-2011", Journal of Eastern Europe Research in Business and Economics , Vol. 2018 (2018), Article ID 563930, DOI: 10.5171/2018.563930 
Comparative regional research on financial, economic and social stress management during the financial and economic crisis in 2008-2011 is extraordinarily interesting, as it includes a set of very similar states historically and economically, but these states chose rather different strategies in 2008-2011 to counter the crisis. The financial crisis management experiences in the Baltic States and Visegrad countries also offer bases for theoretical analysis in terms of transition models and strategies, as the region consists of countries following the shock-therapy model, like Estonia and Latvia, and countries following a model of gradual adaptation, like Lithuania or Poland.

From the Estonian perspective, financial crisis management provided the valuable possibility to research the social and political reaction to the "broken hopes" of long term stability and economic growth, which was expected to arrive after Estonia's accession to the eurozone and Schengen visa-free regime as a reward for years of reforms and efforts.

Estonia's path through the financial crisis in the years 2008-2011 was in many aspects different from the rest of the Baltic States, the Northern countries and the Visegrad states, as during the process of fiscal stabilisation, Estonia also set the goal of fulfilling the eurozone accession criteria (the Maastricht criteria) and joining the eurozone with any cost. This additional demanding goal defined clear limits to the stabilisation and rescue strategies during the hottest stages of crisis. As a result, Estonia was one of the rare societies in the EU and the eurozone where austerity was chosen by the government to combat the financial crises, and this led to strict austerity measures in the years 2009 and 2010.

But the final costs of austerity and financial stability where even higher, as joining eurozone forced Estonia to participate in financial stability mechanisms and bail-out programmes in 2013-2017 Veebel and Markus 2013). Accordingly, the Estonian experience is valuable from the wider future perspective of the European Union and eurozone, as it offers experience and answers \to whether extreme austerity is an efficient solution to counter a financial crisis, the economic and social costs it includes, and the best practices when implementing austerity.

\section{Economic choices for radical fiscal consolidation and actual economic outcomes}

There are two central research questions to be addressed in the following analysis. First, it should establish whether the Estonian government can be considered as a passive policy-taker or an active policymaker during the financial crisis. And second, which were the central variables of governmental policy and strategic communication during the crisis?

The recessions in Estonia can generally be divided into two distinct periods: the first phase lasted from the second half of 2007 to the intensification of the global financial crisis in the autumn of 2008, and the second phase from the autumn of 2008 until the end of the recession by the end of 2009.

The starting economic and fiscal circumstances in Estonia in 2007 were quite specific when compared to its regional neighbours or euro area members. First, there were several positive variables easing the entrance to the crisis: there existed a tradition of balanced central budgets, small central government debt (4.4\% from the gross domestic product (GDP)), and a special reserve fund for a crisis situation. There were also no government bonds issued in the whole history of re-independence.

As Estonia was using the currency board system, government was a passive actor in terms of money supply and interest rates. Additionally, the Estonian budgetary law did not allow to submit budgets even with minor deficit, even when in the EU level the Maastricht rules allowed a 3\% budget deficit for the states applying for euro area membership. There were no limitations to sovereign debt, but at the beginning of the crisis, Estonia did not have a tradition of national bonds. The government's ability to finance a budget deficit was also influenced 
by the actual interest rate asked by the commercial banks.

The first phase of the recession was relatively mild and saw a domestic demand-led adjustment that was primarily related to a deceleration in credit growth. The second phase of the recession, which started with the deepening of the global financial crisis in September 2008, saw a sharp reversal of foreign capital flows and a steep fall in exports. The austerity measures taken in Estonia in 2008-11 were triggered by the fall of foreign capital inflows and lending in the first quarter of 2008, which resulted in FDI dropping from its previous level of 2 billion euros in 2007 to 1.2 billion euros in 2008, causing an immediate drop in GDP in the second quarter of 2008 and a fall in budget revenues (Statistics Estonia, 2013a). As a reaction to the fall in budget revenues, a budget reduction was passed by the parliament of Estonia in June 2008, reducing spending for the rest of 2008 by
384 million euros, which was almost $7 \%$ of the budget.

To reduce growing expenditures, public sector wages were first reduced by around $20 \%$ in the last quarter of 2008 and investments and numerous state procurements were cancelled. Despite these austerity measures, even after the correction the total revenue side of the budget remained in deficit in 2008. The government's austerity policy caused a chain reaction where the reduction of public wages and cancellation of investments and state procurements reduced the government's tax revenues and payments to commercial banks too; as a result, the purchasing power and the ability of the private sector to service the existing debt declined. The only group which fully escaped the cuts in political reasons was pensioners, as the average monthly pension even grew by about $20 \%$ in 2008 , which has been described as the government's 'insurance policy' to maintain political support among voters in an ageing society.

Table 1: Main economic indicators for Estonia, 2007-2012

\begin{tabular}{|c|c|c|c|c|c|c|}
\hline Economic indicator & 2007 & 2008 & 2009 & 2010 & 2011 & 2012 \\
\hline GDP (chain-linked volume growth, \%) & 7.5 & -4.2 & -14.1 & 2.6 & 9.6 & 3.9 \\
\hline Total general government revenue (EUR b) & 5.843 & 5.961 & 5.978 & 5.841 & 6.269 & 6.831 \\
\hline $\begin{array}{l}\text { Change in total general government revenue }(\% \text {, in } \\
\text { comparison to previous year) }\end{array}$ & & 2.02 & 0.29 & -2.29 & 7.33 & 8.96 \\
\hline Total general government expenditure (EUR b) & 5.46 & 6.44 & 6.251 & 5.813 & 6.088 & 6.872 \\
\hline $\begin{array}{l}\text { Change in total general government expenditure (\%, } \\
\text { in comparison to previous year) }\end{array}$ & & 17.95 & -2.93 & -7.01 & 4.73 & 12.88 \\
\hline Net lending $(+) /$ net borrowing $(-)$ & 0.383 & -0.479 & -0.273 & 0.028 & 0.181 & -0.041 \\
\hline Average monthly gross salaries (EUR) & 724.5 & 825.2 & 783.8 & 792.3 & 839 & 887 \\
\hline $\begin{array}{l}\text { Change in average monthly gross wages and salaries } \\
(\% \text {, in comparison to previous year) }\end{array}$ & & 13.90 & -5.02 & 1.08 & 5.89 & 5.72 \\
\hline Civil servants wages from average wages (\%) & 108 & 106 & 96 & 98 & 99 & 101 \\
\hline Monthly average old-age pension (EUR) & 226.3 & 278.4 & 301.3 & 304.5 & 305.1 & 312.9 \\
\hline $\begin{array}{l}\text { Change in monthly average old-age pension }(\% \text {, in } \\
\text { comparison to previous year) }\end{array}$ & & 23.02 & 8.23 & 1.06 & 0.20 & 2.56 \\
\hline Unemployment rate (\%) & 4.6 & 5.5 & 13.5 & 16.7 & 12.3 & 10 \\
\hline Consumer price index $(\%)$ & 6.6 & 10.4 & -0.1 & 3 & 5 & 3.9 \\
\hline Harmonised competitiveness indicator (\%) & 4.2 & 6.1 & 1.6 & -2.8 & 1.3 & -0.3 \\
\hline
\end{tabular}

Source: Bank of Estonia, 2013 and Government of Estonia, 2009 
In 2009, despite previous hard efforts, Estonian budget planners had the even more complicated task of fiscal consolidation in front of them, as government decided to make drastic expenditure cuts across the board in December 2008. The latter were preferred to the targeted cuts which were not used as consensus was not reached on the priority of sectors. The majority of the expenditure cuts were seen as temporary and planned to last for two years (Government of Estonia, 2008). The cuts resulted in a central government budget deficit of $2.9 \%$ which narrowly met the Eurozone accession criteria on government budget deficit (maximum 3\% from GDP is allowed), but was extraordinarily large under the current budget law (which is not allowing deficit at all).

Thus for the first time since Estonia had regained independence, a budget with deficit was planned in 2009. As a result of the drastic budget cuts, Estonia experienced a fall in GDP reaching 14.1\% and a decline in industrial output of $24 \%$, while average monthly gross wages and salaries dropped by $5 \%$ and unemployment increased by 8 percentage points. At the same time, as in 2008, pensions were not cut in 2009 but grew again by $8 \%$ from an average of 278 euros per month in 2008 to 301 euros in 2009.

Although the Estonian economy showed some signs of growth in 2010, the budget for upcoming year was planned in a conservative way. The revenue side of the budget remained in general on the same level as in 2009 at around 5.8 billion euros while spending was cut by about $7 \%$ from 2009. Spending and revenues were balanced mainly due to the government's drastic decision to halt payments into the second pillar of the Estonian pension system. Although payments were restored after two years and the state even increased its contributions to compensate for the losses, the popular belief that the pension system is firm and unshakable has not been restored. In 2010, Estonia finally fulfilled the Maastricht criteria and decided to adopt the euro and join the euro area in 2011. Seen as political success for the government, it also softened public reactions against austerity policy implemented and justified by government.

The government budget for 2011 was planned rather optimistically, based on the view that both the Estonian economy and government spending would be growing. As the Estonian economy saw growth both in terms of GDP and industrial output, a budget deficit was avoided, and revenues exceeded the expenditures by $1.2 \%$ (relative of GDP). Salaries grew together with pensions, and while the growth in the average pension was largely nominal at 1 euro per year, average salaries grew by around 5\% (Statistics Estonia, 2013a). While fiscal factors began to normalize, social tensions and pressure continued, caused by the high unemployment level (12.3\%), reduced healthcare accessibility, high inflation (5\%) and limited credit options by private banks. As a result, labour migration especially towards Nordic countries grew (consisting of both highly educated doctors and construction workers with low education).

In 2012, the GDP growth in Estonia stabilized at $3.9 \%$ and aggregate gross domestic product reached the highest level in the country's history (Bank of Estonia, 2013). Although the budget proposal for 2012 was initially planned to be in deficit with expenditures, exceeding revenues by 0.68 billion euros, at 6.80 billion euros to 6.12 billion euros, in actual terms of fulfilment the budget was more balanced at 6.4 billion euros (Ministry of Finance, 2012). Both wages and pensions continued to grow as average salaries increased by $5.7 \%$ and the average monthly pension by 2.5\% (Bank of Estonia, 2013).

Which were the social effects of austerity measures taken by the government in 2008-11? Despite the government's efforts, costs for social policy were also growing during the crisis, pushed by a quickly growing consumer price index and political promises to raise pensions every year. According to Organization for Economic Cooperation and Development (OECD) data, Estonian social costs grew from $12 \%$ of GDP in 2007 to $18 \%$ of GDP in 2011 (OECD, 2011). To the Estonian labour market, the 
influence of crisis and budget cuts was evident but arriving late. If before the crisis in 2007 the unemployment rate was $4.7 \%$, then in 2008 it rose only to the $5.6 \%$ level since employers tended to hope that the crisis would be short and preferred temporary salary cuts instead of reducing the labour force (Statistics Estonia, 2013a). In 2009, however, unemployment has doubled to the level of $13.8 \%$, and in 2010 it reached the top level of $16.9 \%$, and lowered to the $12.5 \%$ level only in 2011 (Masso and Krillo, 2011).

Average monthly wages, reached 724 euros in 2007, followed by more than $10 \%$ growth to 825 euros in 2008, a decline to 783 euros in 2009, a small growth in 2010 to 792 euros and a 5\% growth in 2011 to 839 euros. What differed in the Estonian wage correction process and dynamics from the other Baltic States was that at the beginning of the crisis, Estonia's public sector salaries were higher than private sector salaries, which turned in an opposite way to the end of austerity (Masso and Espenberg, 2013).

Tax revenues were growing during the years of crisis - starting from $31.5 \%$ of GDP in 2007 , the tax percentage grew to $31.8 \%$ in 2008 and to $35.8 \%$ in 2009 (falling slightly to $34.3 \%$ in 2010 ). While this level is significantly lower than the EU-27 average (39.6\% in 2010), it is higher than tax levels in Latvia (27.5\% in 2010) and Lithuania (27.4\% in 2010). Also, the trends in both southern Baltic States and Europe27 have been different from Estonian choices - while the Estonian government grew the tax share in terms of GDP, the EU27 kept it stable, and Latvia and Lithuania were able to reduce it.

During the years of crisis, social pressure started to influence migration (starting from the year 2010), when emigration grew by $25 \%$ on a yearly basis. In 2011 this growth continued with the speed of $20 \%$ and reached a remarkable $80 \%$ growth in 2012 (Bank of Estonia, 2013).

\section{Political Choices and Communication during the Austerity Period}

How did the Estonian government use the toolbox to achieve fiscal consolidation prescribed by the laws?, which were the main actions indicating the government's role in initiating the austerity policy? and which were the main principles of Estonian austerity policy?

To implement austerity, the Estonian government chose to achieve fiscal consolidation by taking the path of acrossthe-board measures (Pollitt, 2010, 17-18) rather than targeted cuts. Although it is easier to achieve consensus for across-theboard measures, the targeted cuts approach would in an ideal case offer higher economic returns or less social stress. Analysing the duration of the measures (i.e. whether the cuts and the immediate burdens are being introduced as a temporary or a long-term measure), we can see that the government acted exactly according to the theory described by Rubin (1980) and started with the minimum possible cuts in expenditures across the board to compensate for the lack of revenues while hoping that the crisis would prove temporary. Later, the government continued 'slicing' the costs to reach a balance, which it followed with unsuccessful attempts to increase revenues as the economic situation deteriorated and drastic cuts in spending were needed to avoid a budget deficit in 2009 and 2010 . There were not many alternatives to austerity for the Estonian government. Since Estonia had a currency board at the time, the government was unable to influence money supply and interest rates.

Although there were no limitations on sovereign debt, Estonia had no tradition of issuing national bonds at the beginning of the crisis, and although the government had a legal right to change the exchange rate, in practical terms, it rejected this option as it would have resulted in failure to meet the euro area accession criteria. And so austerity focused only on budget corrections. Maintaining and increasing Estonia's investment grade was set as one main priority by the Estonian government during the crisis. At the end of 2011, Estonia had managed to keep an A1 rating by Moody's, AA-/Stable by Standard and Poor's and A+/Stable by Fitch (which was better than Italy's grade and equal to Span's grade). Estonian grades have also been higher than the grades of its Baltic neighbours, which both scored in the range 
of $\mathrm{BB}+/ \mathrm{BBB}$. Despite its efforts, Estonia never joined the countries with triple a AAA rating, symbolising balanced state finances and a stable economy.

With regard to long-term crisis management, the fundamental issue facing the Estonian government during the economic crisis was the question of whether fiscal consolidation should be achieved through cutting costs, increasing revenues or going for both options simultaneously. Since meeting the euro area accession criteria (the Maastricht criteria) was a parallel goal for the government alongside crisis stabilization, the Estonian political elite decided to choose the first option. In this way, the Estonian experience also offers a valuable contribution to the theoretical framework of fiscal consolidation which would generally tend to support the opposite model of immediate gains through revenuebased measures, with spending cuts following only in case revenue raising proves insufficient (see Wolman and Davis, 1980).

In terms of strategic political communication, the Estonian government followed the logic discussed by Katzenstein (1985) and Pierson (1996) for a small state corporatist government where the government presents itself as a policy 'taker' in a partial force majeure situation.

The government purposely took the role of partial actor (policy-taker) who merely tries to save the situation caused by a global crisis. And the government did succeed in convincing the voters that the fiscal situation was desperate and its choices were limited but that full commitment to austerity would save the situation and even if the government did not succeed, it was morally and economically the most sustainable solution.

Was austerity a necessity or the only option for the Estonian government to achieve fiscal consolidation?

In terms of macroeconomic conditions, the decline of the GDP by $14.1 \%$ in 2009 was one of the highest in the EU, but it was lower compared to the Latvian economy which dropped by $-17.1 \%$ and quite equal to the Lithuanian economy decline of
$-14.8 \%$. At least in the Baltic context, the Estonian GDP suffered less than the Latvian or Lithuanian GDPs (Statistics Estonia, 2014). In the Baltic context, Estonia was also the most stable country in terms of budget balance. The highest deficit in Estonia occurred in 2008 reaching 2.9\% only to be followed by $2 \%$ in 2009. In 2007 and 2011, the Estonian budget saw surpluses. Estonia was also the only country among the Baltic States having a special stabilization reserve for the case of economic shocks. Next to witnessing a balanced budget, also Estonian tax revenues were growing during the years of crisis - starting from 31\% of GDP in 2007 and reaching 34\% in 2010. While this level is significantly lower than the EU-27 average (39\% in 2010), it is still higher than the tax levels in Latvia $27.5 \%$ in $2010)$ or Lithuania $(27.4 \%$ in 2010). Estonia started the debt crisis with the lowest debt level (4.6\% of GDP in 2008) in the EU and euro area; Latvian debt reached $19.5 \%$ in 2008 and Lithuania met the crisis with a debt of $15.6 \%$ in 2008. In 2009, governmental debt was growing in Estonia, in all selected reference countries and in the EU on average. While Estonia almost doubled its debt level to a mere $7.2 \%$, Latvia reached 36\% and Lithuania 29\%. The average governmental debt of the European Union's member states in the same time increased from $61.6 \%$ in 2008 to $73.6 \%$ in 2009. One further indicator which can explain Estonia choosing austerity during the financial crisis is inflation. Estonian inflation increased by $6.6 \%$ in 2007 and reached $10.4 \%$ already in 2008 . While there was no direct economic need to counter inflation with austerity, austerity nevertheless offered Estonia an excellent possibility to bring inflation below $3 \%$ which was the main obstacle in its way to fulfilling Maastricht criteria and entering the Eurozone.

Based on the above described indicators, it can be admitted that austerity was not the one and only fiscal choice for the Estonian government. In terms of GDP dynamics, the Estonian situation was better or equal to its Baltic neighbours and in respect of the fiscal deficit and governmental debt, Estonia scored the best results in the euro area and the whole European Union. Hence, 
the main reason for choosing austerity seemed to be the willingness of the Estonian government to reduce the inflation level in order to be able to access the euro area. When looking back to austerity choices from year 2017 and comparing Estonian post-austerity development with Latvian and Lithuanian development, two specific differences are visible. First Estonia ended up with remarkably lower public sector debt $(9,5 \%$ in Estonia compared to $40 \%$ in Latvia and $40 \%$ in Lithuania), but it also ended up with lower economic growth in 2013-2016, which led to the situation where former slowest economic performer Lithuania has bypassed both Latvia and Estonia in terms of GDP per capita per purchase power (27900 USD in Lithuania vs 27700 USD in Estonia).

One major argument used to legitimize austerity as a partial force majeure was the fact that in 2007-13 Estonia was allocated more than 3.4 billion euros from the EU Structural Funds and so Estonia simply had to follow European guidelines (Veebel and Loik 2012). The need to find active support among the member states of the euro area for Estonia's entry was used as another argument.

At least, the Estonian government itself considered its ability to manage the economic crisis and simultaneously maintain voters' support to be an example to follow to others - the Estonian prime minister and the government coalition have expressed the opinion that Estonia was one of the most successful EU members in combating the financial crisis and that other member states of the EU should learn from the experience of Estonia (Ansip, 2012).

\section{Conclusion}

Among the CEE countries and the Baltic States, Estonia has been often symbolizing opened, innovative, competitive economy, social shock therapy models, balanced governmental budget and low debt level (Veebet, Namm and Tillmann 2014). While the years of economic boom in 2004-2007 offered numerous temptations in terms of social spending and institutional investments, the following years (20082011) of pressure and austerity tested the hidden values of political elite, survivability of economy and preferences of population.

When Baltic States were hit by global financial crises, the starting points and strategies chosen for the fiscal consolidation were different. First, the aim to join the OSCE and the Eurozone played an important role for Estonia when choosing its strategy and, in many aspects, different tools from its' Baltic partners during the economic crisis. Second, the goal to join Eurozone was seen as a priority for any cost and fulfilling the Maastricht criteria seemed possible only through austerity and budget cuts strategy (Veebel 2011). Third, there was both political and social consensus that additional costs and loans will not be a part of the solution, rather they would destabilize the situation. Fourth, Estonia was able to choose austerity as having no pressure of long term governmental debt, no tradition of budget deficit and low cost-level for social services. During the financial crisis, Estonia continued its previous practice as hardliner in terms of social security, but added to it an image of committed follower of European solidarity (Veebel 2009)

Estonia and, in many aspects, all three Baltic states offer also a valuable example of economic recovery from very high GDP decline (in 2009 GDP decline topped with $17,7 \%$ in Latvia, $-14,8 \%$ in Lithuania and $14,1 \%$ in Estonia) without devaluation, bail-out or additional loans (Raudla and Kattel 2013, 733).

Especially in financial and legal terms, Estonia followed more the decisions and debates of Finland (than its Baltic neighbours), which is the only Eurozone member next to Estonia among Nordic and Baltic countries. There is also another similarity: Finland and Estonia were the only states next to Luxembourg actually fulfilling Maastricht criteria in 2010 and 2011. Second, main partner and source for Estonia of inspiration in the way towards austerity was Germany. Cooperation and relations between Baltic States, however, remained as formal as they were before.

When looking at the cost of austerity, two problems have grown, which will slow Estonian development in upcoming years; first, the growth of unemployment and 
especially structural unemployment; second, missing investments in energy sector which have resulted in the highest energy costs per person (form GDP) in the EU.

When looking back to crisis years and Estonian government's later comments to crisis experience, no lesson was learned or even seen necessary. On the contrary, according to the opinion of Prime Minister (Andrus Ansip) and Minister of Finance (Jürgen Ligi), Estonia was one of the most decisive, moral and successful member states in solving problems during the crisis and the other member states should learn from Estonia. The only admitted lesson from crisis was that buffers - governmental stability funds need to be bigger because of the possibility of unexpected pressure, but no changes are needed in terms of government revenues and taxes. The philosophical debate on pro-Thatcherism and the opposite classical welfare state model was also used to support the government's argument that austerity is the one and only strategically acceptable solution to the crisis.

Can Estonia's austerity experience serve as an example for other CEE new-comers in Eurozone? It is possible only for the countries that have no high level of governmental debt needing renewing systematically and no tradition of budget deficit. Among the Eurozone members, only Finland and Luxembourg meet these central pre-conditions. Important question to answer before following Estonia's way of austerity is, whether the measures taken supported a long term economic and social stability and growth or lowered competitiveness and social security.

\section{References}

1. Ansip, A. (2012), Speech in Riigikogu. Retrieved http://valitsus.ee/et/valitsus/ peaminister-ja-ministrid/andrusansip/peaministri-koned-jaseisukohad/71892/peaministeransipipoliitiline-avaldus-2013.-aastariigieelarve-\%C3\%BCleandmiselriigikogule,-27.-september-2012

2. Bank of Estonia (2013), Estonia's Economy in 2012, Bank of Estonia. http://statistika.eestipank.ee/?lng=en\#list Menu/1017/treeMenu/MAJANDUSKOOND

3. Estonian Central Office of Statistics (2013), HTTP: <http://www.stat.ee/mainindicators $>$.

4. Government of Estonia (2008), State Budget Strategy 2009-2012, Tallinn.

5. Government of Estonia (2009), State Budget Strategy 2010-2013, Tallinn.

6. Government of Estonian (2012), Estonian government's European Union Policy for 2012-2017

7. Katzenstein, P. (1985). Corporatism and Change, Cornell University Press.

8. Masso, J. and Espenberg, K. (2013), "Baltic States' Public Sectors during the Crisis: early application of fiscal austerity measures", in D. Vaughan-Whitehead (Ed.), Public Sector Shock. The Impact of Policy Retrenchment in Europe, Edvard Elgar, 84133.

9. Masso, J., Krillo, K.; (2011), "Labour markets in the Baltic states during the crisis 2008-2009: the effect on different labour market groups". University of Tartu, Faculty of Economics and Business Administration Working Paper No. 79.

10.Ministry of Finance (2011), database on state budgets, http://www.fin.ee/riigieelarve-2012 and http://www.fin.ee/riigieelarved-2001$\underline{2010}$

11.OECD. (2011), Pro- and anti-social behavior. Society at glance 2011: Social indicators. Paris: OECD Publishing.

12.Pierson, P. (1998). Irresistible forces, immovable objects: post-industrial welfare states confront permanent austerity. Journal of European Public Policy, 5; 4 December 1998

13.Pollitt, C. (2010), Cuts and ReformsPublic services as we move into a new era. Society and Economy 32(1), 17-31.

14.Raudla, R. and Kattel, R. (2013), Fiscal Stress Management During the Financial and Economic Crisis: The Case of the Baltic Countries, International Journal of Public Administration, 36:10, 732-742

15.Riigikogu (2010), Agreement on the terms of accession of the Republic of Estonia to the Convention on the Organization for Economic Co-Operation 
and Development was amended. https://www.riigiteataja.ee/aktilisa/2241/ 1201/0005/Agreement terms.pdf

16.Veebel, V. (2009). European Union's Positive Conditionality model in preaccession process, Trames, (3)13, 207-231.

17.Veebel, V. and Markus, R. (2013). Why and How Supranational Institutions Became Central Stakeholders in the Eurozone Debt Crisis 2008-2012? Baltic Journal of Political Science Vol. (2)2013, 50-66.

18.Veebel, V. (2011). Relevance of Copenhagen Criteria in Actual Accession: Principles, Methods and Shortcomings of EU Pre-Accession evaluation. Studies of Transition States and Societies, 3(3), 3-23
19.Veebel, V; Namm, A and Tillmann, T (2014). Testing the myths of transition: was Estonia following shock therapy model and Slovenia following gradualist model in 1991-2000? Studies of Transition States and Societies, 6(2), 5 - 21.

20.Veebel, V. and Loik, R. (2012). "Estonia: Life in Post-Communist Eastern Europe after EU Membership" In D. O'Beachain (eds.) Life in Post-Communist Europe after EU Membership. Routledge, London.

21.Wolman, H., and Davis, B. (1980), Local government strategies to cope with fiscal pressure. In Charles H. Levine \& Irene Rubin (eds.), Fiscal stress and public policy (231-248). London: Sage Publications. 